Jorge Costadoat, S.J.

Profesor de la Facultad de Teología

Pontificia Universidad Católica de Chile

\title{
La liberación en la cristología de Jon Sobrino
}

El objetivo de este artículo se limita a dar cuenta de los trazos principales de la concepción, el alcance y la importancia de la liberación en las dos obras cristológicas principales de Jon Sobrino. Quedarán fuera de nuestro estudio muchos temas de rico interés cristológico como, por ejemplo, los de la identidad y denominación de Jesús que solo se tocarán a la pasada.

Jon Sobrino es probablemente el principal cristólogo latinoamericano. Su cristología se ha desarrollado a lo largo de por lo menos veinticinco años de publicaciones. Ella es posible recogerla fundamentalmente en dos obras mayores: Jesucristo Liberador (Trotta: 1991) y Fe en Jesucristo. Ensayo desde las víctimas (Trotta: 1999) (1). Cabe subrayar -especialmente a la hora de emitir un juicio crítico sobre el conjunto- que en esta última obra Sobrino declara contentarse con haber publicado un "ensayo" y no una cristología propiamente tal, como había esperado escribirla años antes.

La razón del corte temático señalado más arriba proviene de la naturaleza misma de la cristología de Sobrino. Ella se caracteriza por un interés y una organización soteriológica, referentes a un contexto histórico muy preciso que requiere de una cristología relevante. A comienzos de los años noventa se nos dice: "El contexto, ciertamente, es el que sigue exigiendo no menos, sino más liberación, el que sigue exigiendo una cristología de la liberación" (2). A fines de los años noventa esta necesidad persiste y se agrava (3).

Si hay algo que caracteriza la entera cristología de Sobrino es la convicción de que no basta confesar a Cristo para ser cristianos, que es posible usar su nombre con fines ideológicos y que se requiere volver a Jesús de Nazaret para rescatar su fuerza liberadora. No es posible ser ingenuos. Todas las cristologías responden a intereses y entre estos, sostiene Sobrino, hay que distinguir los que se ajustan a Cristo y los que mueven a tergiversarlo. Dicho con sus propias palabras "la cristología puede ser útil para cosas buenas, pero puede ser utilizada para cosas malas, lo cual no debiera

(1) Particular importancia tendría en un estudio genético del pensamiento de Sobrino el artículo "La verdad sobre Jesucristo", en Jesús en América Latina. Su significado para la fe y la cristología, Santander, 1982, 15-93.

(2) JL 18.

(3) Cf. FC $15-17$. 
extrañar, porque, siendo hecha por seres humanos, está también sujeta a la pecaminosidad y la manipulación. No hay que olvidar que en la historia ha habido cristologías heréticas que han recortado la verdad total de Cristo, y, lo que es peor, que ha habido cristologías objetivamente nocivas, que han presentado a un Cristo distinto y aun objetivamente contrario a Jesús de Nazaret. Recordemos que nuestro continente cristiano ha vivido siglos de opresión inhumana y anticristiana sin que la cristología, al parecer, se diera por enterada y sin que supusiera una denuncia profética en nombre de Jesucristo" (4).

La cristología latinoamericana tiene la virtud de estructurarse soteriológicamente. En su caso, a diferencia de otras cristologías, ella se articula en vista de una salvación que se espera aparezca ya en esta historia. En los apartados siguientes veremos cómo la liberación de los pobres determina medularmente su metodología. Para ser salvación histórica de los pobres, la cristología de Sobrino ha debido rescatar el carácter escatológico de Jesucristo: su doble referencia al reino de Dios y al Dios del reino, y la profunda humanidad e historicidad de Jesucristo. La recepción de esta cristología ha querido ser crítica en el entendido que, situándonos en la brecha que nos abre, lo que nos interesa es ayudarla a avanzar.

\section{RUPTURA METODOLÓGICA}

Bajo el supuesto de que el acontecimiento escatológico ya ha ocurrido, que en la historia Cristo está presente y que su actuación es ya en este mundo verificable para la fe, el método de la cristología de Jon Sobrino se sirve de las posibilidades actuales de la hermenéutica para que la salvación trascendente se haga realidad inmanente entre los pobres. Su intento teológico destaca por explicitar honestamente del "desde dónde" de su cristología y la incidencia del contexto en ella. Si el objeto de toda cristología es Jesucristo, el acceso a su estudio lo cumple Sobrino en circularidad hermenéutica: los textos de la revelación que hablan de Jesucristo se comprenden desde el contexto en que Cristo se hace presente en la historia y, viceversa, los mismos textos iluminan sobre dónde es posible hallar hoy a Cristo en la historia para hacer de este el lugar ideal de la cristología (5). El contexto de la cristología latinoamericana, que por la presencia de Cristo en él puede llamarse "lugar teologal", son "los pobres de este mundo" (6). Este, a su vez, se desdobla analíticamente

(4) JL 13.

(5) "La cristología, para abordar a su objeto Jesucristo, debe tener en cuenta dos cosas fundamentales. La primera, y más obvia, es lo que el pasado nos ha entregado acerca de Él, es decir, textos en los cuales ha quedado expresada la revelación; la segunda, menos tenida en cuenta, es la realidad de Cristo en el presente, es decir, su presencia actual en la historia a la cual corresponde la fe real en Cristo.

Según esto, el lugar ideal de la cristología será aquel donde mejor se puedan comprender las fuentes del pasado y donde mejor se capte la presencia de Cristo y la realidad de la fe en Él" (JL 41).

(6) Cf. JL 48. "Para justificar esta opción, la cristología puede invocar a priori la correlación entre Jesús y los pobres y su presencia en ellos, tal como aparece en el Nuevo Testamento; pero tiene también la convicción a posteriori de que desde la realidad de los pobres todo se le va iluminando más y mejor" (JL 47). Llama la atención, respecto de la Iglesia, la ulterioridad que los pobres adquieren para la cristología. 
en lugar eclesial (donde se conserva el saber acerca de quién es Jesucristo) y lugar social de la cristología (donde los pobres, como "signos" de todos los tiempos, influyen en el modo como abordar a Jesucristo) (7). Pues bien, Sobrino subraya que la consideración del lugar teologal de la cristología latinoamericana, la del lugar teologal-social particularmente, opera una ruptura epistemológica respecto de las cristologías tradicionales (8). El seguimiento de Cristo que en este lugar arraiga permite conocer aún mejor al mismo Cristo (9). En términos muy sencillos, Sobrino afirma: "desde los pobres se piensa que se conoce mejor a Cristo, y ese Cristo mejor conocido es el que se piensa que remite al lugar de los pobres" (10).

La cristología latinoamericana, y la de Sobrino en especial, se caracteriza por comenzar con el estudio de Jesús de Nazaret y su entera dedicación al reino de Dios. A diferencia de otras cristologías que también hacen del Jesús histórico su punto de partida metodológico, la de Sobrino no se interesa directamente por desmitificar la persona ni la obra de Cristo (11), sino, ante el sinsentido de la tragedia de la realidad de los pobres, pretende "despacificar" y "desidolatrizar" a Cristo, de modo que no nos tranquilice ante la miseria y no pueda usarse su nombre para oprimir a nadie (12). Pero no es esta una especie de "jesusología" o un intento de hacer de Jesús una "símbolo práxico" (13), como si fuera posible tomar de Él su aspecto histórico prescindiendo de su carácter trascendente, a semejanza de la investigación de la escuela liberal. Muy por el contrario, la cristología de Sobrino arranca de la fe en la persona divina de Cristo y se articula en función de la fe en Cristo (14). El seguimiento de Cristo en América Latina precede el interés por el Jesús histórico y, a la vez, se alimenta de Él. El seguimiento de Cristo, más precisamente, constituye el camino que conduce de la investigación sobre Jesús al Cristo de la fe de la Iglesia (15). La cristopraxis de liberación en que la cristología latinoamericana pretende consistir, deriva su fuerza de un concepto integral de Cristo, coincidente con el Cristo de la Iglesia, y no meramente del Jesús histórico. La publicación de Fe en Jesucristo lo corrobora ampliamente. Si el punto de partida metodológico de esta cristología es el estudio del Jesús histórico, su punto de partida real es la fe en Cristo.

En definitiva, el seguimiento de Cristo permite superar la discontinuidad histórica con el Jesús de Nazaret a quien reconocemos al Cristo de la fe. Tal seguimiento

(7) "El lugar eclesial es lugar real de la cristología dentro de una realidad más abarcadora: el mundo de los pobres. Ese es su lugar social-teologal. Y digamos que si el lugar, en cuanto eclesial, influye sobre todo en el contenido cristológico -quién es Jesucristo-, el lugar, en cuanto social, influye sobre todo en el mismo modo de pensar cristológico -cómo abordar a Jesucristo-". (JL 51).

(8) "El lugar social es, pues, el más decisivo para la fe, el más decisivo para configurar el modo de pensar cristológico y el que exige y facilita la ruptura epistemológica" (JL 52; ) Más importante que el recurso a las ciencias sociales, es adoptar el mundo de los pobres como perspectiva de la cristología (cf. nota a pie de JL 52).

(9) Cf. FC 20

(10) JL 56.

(11) Cf. JL 74.

(12) Cf. JL 75.

(13) Cf. JL 79.

(14) Cf. JL 79-80.

(15) Cf. JL 59. 
no solo es una exigencia de Jesús, sino además el principio epistemológico de su conocimiento (16). "Conocer a Cristo es, en último término, seguir a Cristo" (17). El mismo camino hizo el Nuevo Testamento: en él, de la misión de Jesús al servicio del reino (su práctica y la exigencia de realizarla) se pasó a la pregunta por la persona de Jesús y, de esta, a la confesión de fe en Él como Hijo y salvador (18). Sobrino sostiene al respecto una doble mistagogía: el Jesús histórico introduce no solo objetiva sino también mistagógicamente en el Cristo de la fe de la Iglesia e, inversamente, "y la afinidad que se obtiene en la práctica del seguimiento es, subjetivamente, la mejor mystagogia para acceder a Jesús y, así, al Cristo" (19).

Para el seguimiento de Cristo, las dos historias cuentan: la historia de los pobres de hoy y la historia de Jesús de ayer. En la medida que el seguimiento de Cristo arraiga en América Latina, en tanto hace suya la perspectiva de los pobres, la cristología que se nutre de Él lleva a recuperar de la figura histórica de Jesús de Nazaret aspectos que de otro modo quedarían ocultos (la relación esencial de Jesús con los pobres, la parcialidad de Dios, la salvación como liberación de la miseria, etc.) (20). Sobrino desarrolla una intuición común en la Iglesia latinoamericana, esta es, que los pobres, que su visión de la vida y del mundo ayudan a comprender mejor las Escrituras e incluso facilitan la labor del teólogo. Para Sobrino, el mundo de los pobres "da que pensar" (devuelve a la cristología la centralidad que tiene para Jesús el anuncio de un reino de vida a los pobres en contra del antirreino de la muerte); "capacita a pensar" (ofrece a la cristología luz para ver la totalidad de la realidad, aunque lo haga desde una parte de ella); y "enseña a pensar" (preserva al quehacer teológico de la ambición en el conocimiento y de la manipulación de Cristo en contra de los pobres, y obliga a recomprender a la teología como intellectus amoris) (21).

Por otra parte, la historia de Jesús, pero no cualquier forma de entender su historia, es decisiva. Cabe preguntarse qué se entiende por "histórico" en el caso de Cristo. Para Sobrino, lo histórico no es puramente lo que pueda acreditarse científicamente como lo prepascual, sino aquello prepascual que fue sobre todo la praxis de Jesús. Al autor le interesa en especial "lo más histórico del Jesús histórico", a saber, "su práctica y el espíritu con que la llevó a cabo", "el conjunto de actividades de Jesús para operar sobre la realidad social y transformarla en la dirección precisa del reino de Dios" (22). Lo más histórico de Jesús es aquello que "desencadena historia", lo que nos es transmitido como encargo para seguir transmitiéndolo", no "aquello que es simplemente datable en el espacio y en el tiempo" (23). Luego el seguimiento de Cristo de que se trata debe continuar en nuestra historia aquella práctica de Jesús que "en su día desencadenó historia”, pues esa práctica histórica fue "desencadenada para ser proseguida" (24). Esto es posible gracias al mismo

(16) Cf. JL 79.

(17) JL 57.

(18) JL 82

(19) JL 82

(20) Cf. JL 42 y 47.

(21) Cf. JL 52-56.

(22) JL 77.

(23) JL 77

(24) JL 77. 
espíritu que hizo a Jesús misericordioso con los pobres y fiel al misterio de Dios y que, en cuanto gracia, orienta y corrige aquella praxis (25). En sentido estricto, el seguimiento de Cristo es pro seguimiento (26).

La novedad metodológica de la cristología de Sobrino tiene por objeto último la liberación de los pobres. Pero, en lo inmediato, se articula en contra de las cristologías tradicionales y de las imágenes alienantes de Cristo que predominan en América Latina (27). La recuperación del Jesús histórico y de su praxis se afirma en oposición y rompimiento respecto de una fe en "un Cristo sin Jesús" que por siglos se ha prestado para mantener a los pobres en la opresión (28). Sobrino rompe con la ingenuidad de la cristología. Para ser más exactos, rompe con el uso ideológico del carácter divino de Cristo. La razón por la cual la cristología latinoamericana adopta como punto de partida metodológico al Jesús histórico es porque es la única manera de rescatar y salvaguardar a Cristo de las distorsiones de su divinización y abstracción, las cuales operan como si con prescidencia de Jesús de Nazaret fuera posible saber en qué consiste ser "cristo" (29). Para Sobrino, de modo semejante a como Cristo revela al Dios verdadero, Jesús revela qué ha de entenderse por Cristo, y no a la inversa (30).

La cristología de Sobrino imita el camino y la intencionalidad evangélica ulterior de la cristología del Nuevo Testamento. Ambas surgen de la necesidad de proclamar a Jesucristo como buena noticia para los pobres. Así como los evangelios volvieron a contar la pasión y la historia de Jesús de Nazaret para confesarlo como el Cristo, esta cristología adopta el camino cronológico, accediendo al Cristo de la fe desde el Jesús de la historia (31). Dicho con sus propias palabras: "De los evangelios, la cristología latinoamericana aprende, pues, dos lecciones importantes. La primera es que no se puede teologizar la figura de Jesús sin historizarla, narrando su vida y su destino. Sin ello, la fe no tiene historia. La segunda es que no se puede historizar a Jesús sin teologizarlo como buena noticia, y así, en referencia esencial a las comunidades. Sin ello, la historia no tiene fe" (32). La ruptura metodológica que venimos reseñando se juega en definitiva en la circularidad hermenéutica entre las comunidades creyentes y Cristo como buena noticia; en otras palabras, se juega en que la cristología vuelva a ser "evangélica" (33). Frente a la pregunta moderna: ¿qué es posible saber de Jesús de Nazaret?, la cristología latinoamericana recoge los

(25) Cf. JL 78.

(26) Cf. JL 79.

(27) Cf. JL 25-33.

(28) "El mecanismo fundamental para posibilitar la escandalosa situación descrita ha consistido, dicho en forma de tesis, en lo siguiente: olvidar y recortar a Jesús de Nazaret, tergiversar así a Cristo y convertirlo frecuentemente en su contrario. Dicho de forma gráfica, de tal manera se ha presentado a Cristo, que el creyente, para serlo, no tenía por qué parecerse a Jesús y por qué seguir y realizar la misión de Jesús a favor de los oprimidos. Lo que Dios había unido, Cristo -el portador de las esperanzas mesiánicas- y liberación de los oprimidos fue separado y aun contrapuesto a través de la imagen de un Cristo sin Jesús" (JL 30).

(29) Cf. JL 61-64.

(30) Cf. JL 63.

(31) Cf. JL 87; cf. JL 61.

(32) JL 92.

(33) Cf. JL 88-92. 
resultados de la crítica histórica, no deduce por cuenta propia criterios apriorísticos de autenticidad. Pero a posteriori, a partir de la semejanza histórica entre la historia de Jesús y la actual, confirma lo histórico de Jesús en la línea de la verosimilitud. Desde la realidad latinoamericana, a partir del seguimiento de Cristo en las comunidades, la cristología infiere que Jesús debió ser y actuar de determinada manera y no de otra (34).

\section{RELATIVIDAD FUNDAMENTAL DE CRISTO}

Un rasgo distintivo de la cristología de Jon Sobrino es su estructuración escatológica, debida al redescubrimiento de la teología del siglo XX de la referencia fundamental de Jesús de Nazaret al reino de Dios, pero sobre todo a la urgencia de liberación de los pobres. Para Sobrino, Jesús refiere de un modo decisivo y definitivo a lo que él llama "lo último" (el eschaton): Dios y el reino de Dios. Su opción es consciente. Muy al comienzo de Jesucristo Liberador repudia una imagen alienante de Cristo en América Latina que lo concibe como "absolutamente absoluto", en perjuicio de su relatividad al reino de Dios y al Dios del reino (35). Esta relatividad fundamental de Cristo cumple en la cristología de Sobrino una función hermenéutica clave.

Ante sus contemporáneos, Jesús no reclamó para sí mismo una atención central (36), sino que dedicó su vida al anuncio de la buena noticia del reino de Dios (37). El "reino de Dios" y su "Padre" articulan el sentido último de su vida: "...con "reino de Dios', Jesús expresa la totalidad de la realidad y aquello que hay que hacer, y con 'Padre', Jesús expresa la realidad personal que otorga sentido último a su vida, aquello en lo que Jesús descansa y lo que, a su vez, no le deja descansar" (38). Lo último, sin embargo, no son dos realidades separadas ni separables, sino una "unidad dual o una dualidad unificada", por cuanto el reino no se concibe sin Dios ni Dios sin el reino, implicándose recíprocamente en lo último su dimensión trascendente y su dimensión histórica (39). A partir de lo último para Jesús, Sobrino intenta explicar, organizar y jeraquizar sistemáticamente la praxis de Jesús, su vida interior y su destino de cruz (40). Pero al articular escatológicamente su cristología, Sobrino, a diferencia de teólogos como Pannenberg (41), subraya la necesidad de verifi-

(34) Cf. JL 88-90.

(35) Cf. JL 32.

(36) JL 95

(37) Cf. JL 144ss.

(38) JL 95.

(39) "Esto significa que Jesús expresa lo último en una unidad dual o en una dualidad unificada. En lo último siempre está Dios y algo que no es Dios. Y por ello hay que hablar de Dios y de reino; o, en otras formulaciones, hay que hablar de Dios $y$ de voluntad realizada de Dios, de Dios $y$ de pueblo de Dios, etc. Para Jesús, por tanto, lo último tiene una dimensión trascendente y una dimensión histórica. Esta dependerá de aquella, y por ello, lo que sea el 'reino' dependerá, en último término, de lo que sea 'Dios'...; pero también, a la inversa, la comprensión de Dios dependerá de lo que sea el reino. Lo que hay que recalcar es que, para Jesús, Dios no es una realidad que pudiera no relacionarse con la historia ni la historia con Él, sino que esa relación le es esencial al mismo Dios" (JL 97).

(40) Cf. JL 95

(41) Cf. JL 151-156. 
cación inmanente del eschaton. Que lo último sea una realidad futura que encontrará cabal cumplimiento cuando "Dios sea todo en todo" (1 Cor 15, 28), no está en discusión, pero ello constituye la dimensión trascendente de una salvación que ya ahora debiera traducirse en liberación de los pobres. De aquí que resalte la importancia que tuvieron para Jesús la historización del reino y la revelación actual de Dios como Padre.

Respecto del carácter escatológico del reino de Dios, afirma que, en cuanto al “mediador", Jesús, este ya ha llegado (42). Pero en cuanto a la "mediación", la voluntad de Dios cumplida históricamente, esta aún está pendiente (43). Para que el reino llegue, Sobrino deduce la necesidad de determinar un "primado" en la realidad, el cual para la cristología latinoamericano es la liberación de los pobres. De la elección de este "primado" histórico depende que "lo último" para esta cristología sea el reino de Dios y no la resurrección de Cristo. La resurrección podría serlo y de hecho lo es para muchas cristologías, pero ella resulta abstracta para indicar cómo ha de configurarse la historia presente (44). Es más, la resurreción como "lo último" pudiera fomentar "un individualismo sin pueblo, una esperanza sin praxis, un entusiasmo sin seguimiento de Jesús; en suma, una transcendencia sin historia, un Dios sin reino" (45). Por cierto que Sobrino considera la importancia máxima de la resurrección, pero lo hace en el horizonte más amplio y más concreto del reino de Dios (46).

Sobrino lleva la exigencia de historización del reino aún más lejos, hasta el plano de la conflictividad humana. El reino no acaece en una especie de historia "neutra". Su advenimiento exige la erradicación del antirreino, pues este no solo representa el todavía-no del reino, sino el ciertamente-no del reino (47). En la historia no hay término medio, pues en ella reino y antirreino se excluyen (48). La salvación que implica el reino es histórica y tiene múltiples aspectos, pero sobre todo ella supone una lucha y un conflicto. También por esto se la llama "liberación".

El reino de Dios es una realidad a la vez histórica y trascendente. Su concepto sistemático es, según Sobrino: "la vida justa de los pobres abierta siempre a un "más" (49). Con lo de "vida" se alude al carácter histórico y utópico del reino, al don protológico mínimo de Dios y que los pobres no pueden dar por supuesto, porque la muerte se los arrebata a diario. Con lo de "justo" se indica su aspecto liberador (50). "Vida justa" refiere a la índole evangélica del reino, pero también al conflicto que conlleva conseguirla. Que esta vida justa quede "abierta siempre a un más”, significa que, comenzando por el mínimo aquel que los pobres necesitan para

(42) Cf. JL 146-147.

(43) Cf. JL 145.

(44) JL 166.

(45) JL 166.

(46) Cf. JL 166.

(47) Cf. JL 167.

(48) "La llegada del reino está en relación duélica con el antirreino. Ambos no solo son excluyentes, sino que uno hace contra el otro, y esta es una evidencia que se impone masivamente en América Latina: el reino no se construye desde una tabula rasa, sino en contra del antirreino, y como verificación eficaz de ello aparece la persecución contra los actuales mediadores del reino" (JL 167-168).

(49) JL 173.

(50) Cf. JL 174. 
vivir, ella, sin embargo, no se agota en ninguna de sus posibilidades y exigencias, pues tampoco la muerte puede vencerla. "Reino de Dios es radical superación de la muerte, y es expresión de vida y de vida abundante" (51). A esta llama Sobrino la transcendencia histórica del reino. La trascendencia teologal del reino, en cambio, designa a la virtualidad que tiene este para revelar a Dios como el "Dios de la vida" y, más precisamente, como el "Dios de la vida de los pobres" y "Dios de las víctimas" (52).

Respecto de Dios, Sobrino elucida su concepto a partir de la referencia de Jesús al mismo reino (53). También en este plano la cristología se articula escatológicamente: Dios para Jesús es alguien bueno, pero al mismo tiempo trascendente. Porque es bueno lo llama "Padre", porque es trascedente lo llama "Dios". En su "Padre" confía, descansa. A su "Dios", que no lo dejar descansar, se hace radicalmente disponible. "Lo último personal para Jesús es, entonces, Dios-Padre, y su relación con Él es de confianza-disponibilidad. Dios fue para Jesús, y lo fue cada vez más, una realidad sumamente dialéctica: absoluta intimidad y absoluta alteridad" (54). La referencia de Jesús a Dios-Padre, irreductible en sus dos aspectos, constituye el factor preciso de su anuncio del reino a los pobres. Un Dios así, bueno y exigente, ama a los pobres y urge su liberación. El reino representa la voluntad de Dios a la que Jesús se sabe llamado a servir.

De modo semejante a cómo Sobrino historiza el reino de Dios, historiza, por decirlo así, al Dios de Jesús. En Jesús es posible advertir una ilustración acerca del verdadero Dios, en contra de las divinidades de la muerte. Jesús mantuvo una praxis profética -controversias, desenmascaramientos y denuncias- en defensa del Dios verdadero (55). Ella tuvo lugar en medio de una estructuración de la sociedad y el mundo, persistente hasta nuestros días, que Sobrino llama "estructura teologal-idolátrica de la realidad": "En la historia existe el verdadero Dios (de vida), su mediación (el reino) y su mediador (Jesús), y existen los ídolos (de muerte), su mediación (el antirreino) y sus mediadores (los opresores). Las realidades de ambos tipos no son solo distintas, sino aparecen formalmente en una disyuntiva duélica. Son, por tanto, excluyentes, no complementarias, y una hace contra la otra" (56). En un mundo organizado según esta lucha histórica y escatológica, Jesús revela a un "Dios antagónico" (57), un Dios incompatible con la idolatría. Por esta razón la idolatría constituye el polo dialéctico de la cristología latinoamericana, así como el ateísmo ha podido serlo de las cristologías del Primer mundo. "Jesús no ilustra el que haya Dios, pero sí ilustra qué Dios hay” (58). En América Latina no se trata de desmitifi-

(51) JL 176

(52) Cf. JL 176.

(53) Cf. JL 179.

(54) JL 183.

(55) Cf. JL 211ss.

(56) JL 213.

(57) Cf. JL 249.

(58) ¿Quién es Dios, pues, para Jesús? En positivo ya lo hemos visto antes: un misterio que es Padre y un Padre que sigue siendo Dios. Esa es la realidad de Dios, inintercambiable en sí misma con ninguna otra cosa. Pero para poder afirmar eso tan positivo, Jesús ilustra sobre cómo los seres humanos tendemos a tergiversarlo y a manipularlo. Descriptivamente lo hemos visto en sus 
car la imagen de Dios, sino de "desidolatrizarla" (59); de determinar "en qué dios no se cree y qué dios se combate" (60).

En la cristología de Jon Sobrino Jesús refiere histórica y escatológicamente al reino de Dios y al Dios del reino, pero de un modo concreto, principal y ulterior Jesús refiere a los pobres. La relatividad de Jesús a los pobres y de los pobres a Jesús, que para el autor tiene un carácter invariable, justifica la organización de la cristología en los términos recién descritos. La relación entre Jesús y los pobres, entre Jesús y las víctimas, adquiere para Sobrino un valor "metaparadigmático" (61). Los cambios de paradigma que inquietan a los teólogos en la época reciente, no afectan al signo de todos los tiempos. Este sigue siendo, como pensaba I. Ellacuría, el "pueblo crucificado" (62). En contra del olvido de la doble referencia de Jesús al reino de Dios y al Dios del reino, olvido que se traduce en cristologías que se centran en la persona de Jesús y universalizan prematuramente la salvación, Sobrino asegura el carácter sacramental que los pobres y las víctimas tienen para pensar teológicamente. Su realidad ilumina sobre "qué es lo divino y qué es lo humano, y al Cristo que los unifica" (63). No es que a los pobres se ofrezca una comprensión inmediata y superior de las Escrituras, pero su lugar en el mundo es privilegiado para leer los textos que se refieren a Cristo (64). Al mismo tiempo, el Cristo mejor conocido a partir de los pobres "ayuda a conocer mejor a las víctimas y, sobre todo, a trabajar en su defensa" (65). La circularidad hermenéutica entre los pobres y Jesucristo tiene en última instancia una importancia soteriológica. Una cristología así estructurada pretende recuperar el talante de buena noticia que toda cristología debiera tener (66).

La relatividad ulterior de Jesucristo a los pobres constituye el principio de verificación del eschaton. La oferta universal de salvación contenida en el advenimiento del reino por parte de un Dios que es Padre de toda la humanidad, se cumple históricamente de acuerdo al principio de la "parcialidad", de la identificación de Cristo con los pobres, y en virtud de una praxis que, como la de Jesús, defienda a

controversias, desenmascaramientos y denuncias. La conclusión, en lenguaje sistemático, es la siguiente. Ese Dios-Padre es antagónico y está en lucha con otros dioses, y por ello, la fe tiene que ser antiidolátrica. Ese Dios no tiene imagen, pero tiene voz, y por ello la fe tiene que ser práxica, responder a la voluntad de Dios. Ese Dios tiene una palabra que permanece constante: que los seres humanos hagan real en la historia su propia realidad, que consiste en defender a los pequeños, y por ello, la fe tiene que ser realización de la misericordia, de la justicia, del amor. Y ese Dios sí tiene -desconcertantemente- una imagen, un lugar privilegiado en la historia: los rostros de los pobres y oprimidos, y por ello, la fe tiene que ser encarnada y parcial. Como decíamos al principio, Jesús no tiene mucho que decir sobre la cuestión de Dios hoy si esta es vista puramente desde el ateísmo, desde la existencia o no existencia de Dios. Pero tiene mucho que decir, hasta el día de hoy, si preguntamos quién es Dios y qué hacer con Dios. Jesús no ilustra que haya Dios, pero sí ilustra qué Dios hay" (JL 249-250).

(59) JL 243.

(60) JL 243.

(61) Cf. FC 18.

(62) Cf. FC 17.

(63) JL 21.

(64) Cf. FC 19.

(65) FC 20.

(66) Cf. JL 21 y FC 21. 
los pobres (67). En la medida que hay salvación para los pobres lo habrá para los demás. Por cierto el "pobre" en Sobrino constituye un término análogo: se puede ser "pobre" de varias maneras, pero no de cualquier manera (68). El principal analogado del pobre son los pobres materiales, "los económica y sociológicamente pobres", aquellos a los cuales Dios ofrece el reino (69). Los demás acceden a la salvación en la medida que participan en algún sentido del concepto sistemático de "pobre" (70). Por esta vía, la de la parcialidad de Dios, cree Sobrino que se universaliza la salvación escatológica.

\section{RECUPERACIÓN DE LA HUMANIDAD DE JESÚS}

La fe en Cristo en América Latina ha sido incapaz de cambiar la realidad de los pobres, según Sobrino, porque ella se centra en un Cristo más divino que humano (71). Este Cristo ha sido enseñado por la Iglesia institucional. En todas las imágenes alienantes de Cristo en Latinoamérica, el aspecto trascendente prevalece sobre su historicidad y humanidad concretas, sea cuando esa fe recae sobre un Cristo meramente sufriente (que solo mueve a la resignación), sea cuando ella consiste en un Cristo "abstracto" (el Cristo-amor o el Cristo-poder, imágenes que se nutren de un concepto previo de amor y de poder, y no de cómo Jesús fue amor y de qué clase fue su poder), en un Cristo "reconciliador" (que no tiene cuenta de las denuncias proféticas de Jesús y de sus conflictos) o en un Cristo "absolutamente absoluto" (que no refiere al reino de Dios ni al Dios del Reino) (72). En contra de una grave e intencionada tergiversación de Cristo, Sobrino se aboca a ilustrar sobre la imagen emergente del "Cristo liberador", proveniente de Jesús de Nazaret y a destacar de Él su humanidad e historicidad.

La adopción del Jesús histórico como punto de partida metodológico de la cristología latinoamericana tiene por objeto precisamente subsanar esta falencia e impedir la manipulación de Cristo. La circularidad hermenéutica que Sobrino establece entre el Jesús histórico y el seguimiento de Cristo en la perspectiva de los pobres y las víctimas, supone la "realidad" (73) de la humanidad de estos y de aquel

(67) Cf. FC 320-321.

(68) Cf. JL 168-170. Sobrino recurre a Ellacuría para determinar qué entiende por "pobres". Pobres son, en primer lugar, los "materialmente pobres", "las grandes mayorías del Tercer Mundo". En segundo lugar, "los empobrecidos, los oprimidos". Luego, los que toman conciencia de su situación individual y colectivamente. En seguida, "son los que convierten esa toma de conciencia en organización popular y en praxis". Por último, "pobres son los que viven su materialidad, su toma de conciencia y su praxis con espíritu, con gratuidad, con esperanza, con misericordia, con fortaleza en la persecución, con amor y con el mayor amor de dar la vida por la liberación" (JL 169).

(69) Cf. JL 170.

(70) "Para los pobres es el reino, porque son materialmente pobres, y el reino es para los no-pobres, en la medida en que se abajan a los pobres, los defienden y se dejan imbuir del espíritu de los pobres" (JL 170). En otro lugar el autor afirma la universalización de la esperanza generada por la resurrección en tanto se participa análogamente en la "vida y muerte de las víctimas" (cf. FC 70-71).

(71) Cf. JL 25.

(72) Cf. JL 25-33.

(73) En lo sucesivo se destaca el uso por Sobrino del término "realidad". Cabe decir que la importancia de su uso es enorme en la entera cristología del autor, aun cuando no defina suficientemente 
como común denominador y como principio epistemológico recíproco para comprender la praxis, la cruz, la resurrección o la totalidad de lo real. El seguimiento de Cristo en un mundo de pobres exige que se reconozca la plena humanidad de Jesús crucificado y resucitado, y esta, a su vez, posibilita, ilumina e impulsa un seguimiento histórico según el ejemplo de Jesús y bajo el influjo de su Espíritu. En estos términos la cristología de Sobrino cumple su interés soteriológico.

Al abordar el estudio de la cristología conciliar, Sobrino intenta una vez más recuperar la "realidad" de la humanidad de Jesús. La primera obra del autor, Jesucristo liberador, ha abierto el camino a la segunda, Fe en Jesucristo, de modo semejante a cómo en el Nuevo Testamento el Jesús prepascual conduce a la confesión de Él como el Cristo de la fe y a semejanza también de cómo para Sobrino el homo verus Jesús especifica qué ha de entenderse por el vere homo de la cristología conciliar. El olvido de esto último ha hecho que los textos conciliares que contienen el dogma cristológico formulado en los primeros siglos del cristianismo, no obstante su enorme utilidad y normatividad, sean "también limitados y aun peligrosos". Ellos "ponen a la cristología en un camino novedoso y ambivalente" (74). De aquí que Sobrino intente "historizarlos" en la perspectiva de las víctimas.

Desde esta perspectiva, es posible detectar lagunas teológicas importantes en los textos conciliares: la falta de relatividad de Jesús de Nazaret respecto del reino de Dios y del Dios del reino, y su conflicto con el antirreino y los ídolos; y un reduccionismo en la concepción de la salvación, olvidándose que los pobres son sus primeros destinatarios (75). Sobrino centra su crítica en la patrística que hizo posibles tales textos. La comprensión teórica de Cristo, a lo largo de la historia posterior al Nuevo Testamento, se irá fundando "en la constitución ontológica de su realidad, se favorecerá la trascendencia sobre la historia y la encarnación/nacimiento en el origen sobre la resurrección en el futuro, todo lo cual dejará en mayor penumbra la historia de Jesús" (76). A diferencia del Nuevo Testamento que volvió al "principio de realidad", Jesús y su historia, la patrística se alejará de Él, aun cuando no lo pierda del todo. Si el Nuevo Testamento salvaguardó la identidad histórica de Jesús en términos narrativos, la patrística lo hizo concibiendo al mismo Jesús en términos de "naturaleza", pero deshistorizando a Cristo (77) e impidiendo que Él pueda revelar a cabalidad qué es la divinidad y qué la humanidad (78).

su concepto. En un sentido general se puede afirmar que "realidad" se opone a toda forma de "docetismo", lo que en teología sucede cuando se resta verdad e importancia a los seres humanos o a Dios mismo en su capacidad de encarnarse. Contra diversas formas de docetismo, Sobrino exige que se reconozca la "realidad" de los pobres en su relación con la "realidad" del Hijo de Dios encarnado.

(74) FC 317.

(75) Cf. FC 319.

(76) FC 322. "En la patrística todo se irá concentrando, poco a poco, en la encarnación -creída como acontecimiento real-, pero de tal manera transcendente que lleva a minusvalorar lo concreto de la vida de Jesús". Es así que tuvo lugar "una devaluación del 'principio de realidad"” (FC 326).

(77) “Con solo la categoría de 'naturaleza' se pierde la historia y la libertad, lo concreto y lo parcial de Cristo, y esto es lo que hay que mantener" (FC 345).

(78) Esta crítica de Sobrino no es indeterminada, pues reconoce valor a la cristología conciliar proveniente de la patrística más allá de la filosofía griega en que expresa el dogma: "Al hacer uso de ese concepto (naturaleza) se intentará comprender a Cristo y su novedad a partir de algo que, en principio, ya es conocido o al menos cognoscible. Es decir, se presupone lógicamente que ya 
Frente al gnosticismo, la Iglesia afirmó que en Cristo su humanidad es real no obstante su divinidad (79). Como condición de posibilidad de nuestra salvación, Cristo debía ser vere homo (80). Los apologetas tuvieron el valor de afirmar contra los gnósticos que "sea lo que sea 'ser humano', 'eso' es Cristo" (81). Todo lo humano es real en Cristo y en Él "es real nada más que lo humano" (82). Pero la patrística olvidó aquello en que insiste la cristología latinoamericana, a saber, que Cristo es también y sobre todo homo verus (83). Ella no considera que la naturaleza humana de Jesús es cognoscible por su historia. Dicho de otra forma, que "lo contrario de lo verdaderamente humano no es ausencia de humanidad (o de alguno de sus componentes), sino presencia de inhumanidad (a través de un ejercicio espurio de lo humano)" (84).

Esto no obstante, Sobrino sale al rescate del fondo implícito de las definiciones conciliares. En Nicea los padres tuvieron la "audacia y honestidad" para declarar la divinidad de un crucificado. En contra de Arrio, el concilio realizó una auténtica deshelenización del cristianismo. La afirmación del homousios, aunque concibió a Cristo a partir de su origen trascendente (y no a partir de la vida y destino de Jesus), sirvió de principio para distinguir lo humano de lo divino y para atribuir a Dios señorío sobre toda la historia humana. Al hacer de Dios el fundamento último del ser de Cristo, el concilio no superó el esencialismo de la filosofía griega (85). Sin embargo, al hacer espacio a Jesús en Dios, Nicea deja asentado el principio de la concreción y la parcialidad de Dios. En el fondo de la definición de Nicea está implícita la idea de que Dios sufre con los hombres, autodeterminándose a quedar expuesto a ellos. Al aceptar los padres la divinidad de un Cristo sufriente, el concilio mantuvo la novedad (escandalosa y bienaventurada) del Nuevo Testamento y la condición de "afinidad" indispensable para la salvación de la humanidad sufriente (86).

En contra de la tentación perenne del docetismo, que a lo largo de los años ha negado realidad al nacimiento, vida pública, muerte y resurrección de Jesús, a la verdad de su encarnación y a la de sus sufrimientos (87), Sobrino exige de la cristología defender la humanidad de Jesús "sin añadidos" (poderes o conocimientos divinos extraordinarios), pero también recuperar el carácter histórico, dialéctico y concreto de la humanidad de Jesús (88). Pues no basta asegurar lo humano en

sabemos con anterioridad a Jesús qué es divinidad y qué es humanidad para poder decir que en Cristo se verifican ambas realidades. Desde este punto de vista el dogma solo añadiría un saber nuevo: el modo de relacionarse ambas naturalezas en la única persona de Cristo, aunque este específico saber sea muy importante, como veremos, y en este punto el dogma sí expresaría revelación" (FC 346).

(79) Cf. FC 391

(80) Cf. FC 391.

(81) FC 392.

(82) FC 392.

(83) Cf. FC 491-493.

(84) FC 392.

(85) "En Nicea el Hijo es declarado consustancial por lo que Jesús es (nacido unigénito del Padre), pero no por lo que Jesús hace" (FC 373). Aunque Jesucristo esté dentro de la divinidad, "persiste la universalización versus la parcialidad" (FC 373).

(86) Cf. FC 375-376.

(87) Cf. FC 393.

(88) Cf. FC 402-404; 392. 
general de Jesús (vere homo), sino que urge rescatar la misericordia, la entrega y la solidaridad de Jesús (homo verus), en oposición dialéctica respecto de lo "inhumano". Desde la perspectiva de las víctimas, desde su "realidad" de pecado y de gracia, piensa Sobrino que es posible y necesario recuperar al hombre Jesús como "principio de realidad" de la cristología y, en última instancia, como "interpelación a ser real" ante el peligro del docetismo social y eclesial (89).

Pero el "principio de realidad" en Cristo -y por extensión en el caso de toda realidad humana- no es meramente Jesús de Nazaret. Calcedonia asegura que la unidad de la divinidad y la humanidad en Cristo depende en última instancia de su "realidad divina" y, por ende, expresa al misterio. Los padres del concilio tuvieron la audacia de afirmar en Cristo una "totalidad" unificada, sin mezcla, de trascedencencia y de historia: "así, Calcedonia afirmará que Jesucristo es una única realidad, divina -afirmación comprensible en principio- y no dos, que subsiste en dos formas de realidad, en dos naturalezas, humana y divina, cuya relación describió con los conocidos adverbios inconfuse (sin confusión), inmutabiliter (sin cambio), indivise (sin desunión), inseparabiliter (sin separación)" (90). El pathos de totalidad de los padres respetó el misterio santo de Jesucristo que une en sí paradójicamente dos realidades sin explicar cómo. La perspectiva de las víctimas abre la posibilidad para pensar que en la encarnación, tal como la entiende Calcedonia, Dios asume lo "pequeño, débil, limitado y mortal" (91) y, por otra parte, que lo humano en toda su pequeñez puede manifestar a Dios, "aunque sea como Deus absconditus" (92).

Con la expresión "en dos naturalezas", Calcedonia salvaguardó, en términos generales, la humanidad de Cristo. Según el concilio, en la encarnación "la humanidad sigue siendo verdadera, también después de ser asumida por el Logos" (93) e, inversamente, lo humano en su debilidad es "capaz de ser portador de Dios, sin dejar de ser humano y débil" (94). Porque en la encarnación el hombre Jesús sigue siendo Dios, Él merece una correspondencia de fe y porque en Él lo humano sigue siendo humano, exento de un superpoder y una superciencia, aunque dotado de sus posibilidades propias, es que humaniza y salva (95). Al decir que la unión de las naturalezas es "sin separación", esto es, "para siempre", Calcedonia afirma por extensión que solo lo humano puede conducir a Dios y, sin lugar a dudas, lo auténticamente humano (96).

Con el término prósopon o hypóstasis Calcedonia afirmó la realidad divina última de Cristo y que esta constituye el principio metafísico de unidad en Él de su

(89) La encarnación expresa "la voluntad de realidad" de Dios mismo, voluntad "de hacerse real en lo débil de la carne, no en cualquier carne, sino en la carne de los pobres y las víctimas. Esa voluntad de ser sarx opera como el "principio de realidad"' (FC 408). Ante la posibilidad de un "docetismo social" e incluso "eclesial", "hoy en día ser real es, ante todo, estar activamente en la realidad más densa, la injusta pobreza e indignidad, dejarse afectar por ella y reaccionar adecuadamente ante ella" (FC 406).

(90) FC 411.

(91) FC 415-416.

(92) FC 416.

(93) FC 420.

(94) FC 421.

(95) Cf. FC 421.

(96) Cf. FC 422. 
divinidad y de su humanidad. Para el concilio "lo que sea último e incomunicable de la realidad concreta de Cristo está en el Hijo, no en su naturaleza humana", es decir, "que aquello que sea 'último' en Cristo es divino" (97). Cristo representa la radicalidad de la iniciativa divina de comunicarse al hombre humanamente y, a la vez, que lo humano solo en Dios encuentra su principio de realización. La salvación proviene de Dios en Cristo, pero como plenificación de lo humano (98). Aun más, Sobrino descubre en la unidad de Cristo, máxima "expresión irrepetible y suprema de la realidad" (99), la superación de todo maniqueísmo, marcionismo y dualismo. En virtud de la unidad del Hijo encarnado, podemos esperar que el final de la historia se resuelva en una recapitulación pacífica, en un encuentro y no en un desencuentro (100).

Sobrino, empero, descubre en la fórmula de Calcedonia el mismo defecto de la patrística. Si la cristología patrística carece de concreción, de historia y de relacionalidad (101), "la limitación fundamental de la fórmula (de Calcedonia), raíz de todas las demás, es el concepto de naturaleza que excluye la historia en la concepción de la realidad e historicidad en la concepción del ser humano" (102). Al comprender en Cristo la relación de la divinidad y humanidad en términos de naturaleza y no de libertad, ella impide ver al Dios que asume como el Dios del Antiguo y Nuevo Testamento, por una parte, y, por otra, que lo humano asumido en su debilidad y en cuanto víctima, aun con su capacidad de compasión, solidaridad y entrega, constituya la condición para que Cristo alcance su perfección (103). El mérito del concilio de Constantinopla III estriba precisamente en haber remitido la cristología a Jesús. En contra de los monoteletas, aquel aseguró que correspondía a la naturaleza humana de Cristo una voluntad humana y, en principio, que había que reconocer en Jesús una libertad e historia humanas auténticas, esenciales para conocerlo a Él mismo y a su Dios (104).

De aquí saca Sobrino la exigencia actual, de cara a nuestra salvación y en contra del docetismo recurrente, de reconocer a Jesús "persona" humana (105). Que el término "persona" traduzca el prósopon y la hypóstasis que dicen el principio divino en Cristo, no quiere decir que en Él su ser divino anule su ser humano, ya que en la cristología conciliar el término "persona" se usa en sentido ontológico y no antropológico (106). Pues bien, Sobrino sugiere usar el término "persona" para comprender mejor la humanidad de Jesús, sea en el sentido hegeliano de "entrega", sea en el sentido zubiriano de "dinamismo de la suidad" (107). Si la "filiación

(97) FC 423.

(98) Cf. FC 424.

(99) FC 421. La falta de definición del concepto de "realidad" antes señalado se volatiliza cuando se atribuye igualmente a la humanidad de Jesús asumida en la Encarnación y a la identidad divina última del Hijo hecho hombre, en virtud de la cual su humanidad particular y la humanidad en general es unificada.

(100) Cf. FC 424.

(101) Cf. FC 425-439.

(102) FC 424.

(103) Cf. FC 424ss.

(104) Cf. FC 401.

(105) Cf. FC 401.

(106) Cf. FC 423.

(107) Cf. FC 434. 
divina" de Jesús, gracias al concepto de naturaleza, ha podido ser concebida como "proveniencia", Sobrino cree en cambio que es posible entenderla como "entrega": "ser persona es poder entrar en relación con un otro, lo que se consuma en la entrega, de modo que Jesús se constituye en persona precisamente en la entrega a ese otro que es Dios" (108). En este sentido es posible "repensar la filiación a partir de la relación histórica de Jesús con su Dios Padre" (109). En el segundo caso, Sobrino pretende rescatar en la fórmula de Calcedonia -que nada dice explícitamente de ello- la relación de Jesús con el reino de Dios. Si se acepta en clave zubiriana que la persona se expresa en sus actos y no puede ser pensada como anterior a ellos, y si el reino de Dios constituye para Jesús la "voluntad de Dios", entonces la dedicación completa de Jesús a hacer esta voluntad, su praxis, es lo que hace de Jesús una persona humana (110). La intención de Sobrino y la similar de otros autores, nos parecen válidas siempre que no se olvide que en Calcedonia "persona" o hypóstasis eran los términos para decir la unidad en Cristo y que "naturaleza", en cambio, sirvió para expresar su dualidad. De lo contrario, al usar "persona" para denominar su naturaleza humana se incurriría en una grave confusión terminológica.

\section{LA SALVACIÓN COMO LIBERACIÓN}

La cristología de Sobrino tiene la virtud de articularse soteriológicamente. Es la opresión de los pobres la razón exacta que urge al autor a pensar a Cristo en perspectiva escatológica, a profundizar en su humanidad y, sobre todo, a concebir la salvación como liberación histórica. En lo inmediato, la obligada referencia al contexto latinoamericano otorga a esta cristología una relevancia histórica sin igual entre las cristologías.

El punto de arranque de la cristología de Sobrino es la constatación de que en América Latina la fe en Cristo no ha sido salvífica, sino que, muy por el contrario, ha mantenido a los pobres en su miseria cuando no ha justificado su opresión. Las diversas imágenes de Cristo presentes en el imaginario religioso de los latinoamericanos son para Sobrino todas alienantes y, por esto, funcionales a los intereses de los opresores. La imagen predominante de un Cristo sufriente ha otorgado a lo sumo a los pobres paciencia y resignación ante una cruz que les ha sido impuesta (111). Tanto el Cristo de las mayorías del pueblo pobre como el Cristo promovido por la institución eclesial comparten un error que, desde el punto de vista de la verificación histórica de la salvación escatológica, ha resultado fatal. Este es el de una grave distorsión: "lo que Dios había unido, Cristo -el portador de las esperanzas mesiánicas- y liberación de los oprimidos fue separado y aun contrapuesto a través de la imagen de un Cristo sin Jesús" (112).

(108) FC 435.

(109) FC 436.

(110) Cf. FC 437.

(111) Cf. JL 26.

(112) JL 30. 
Sobrino celebra, sin embargo, que en los últimos años, bajo el influjo y amparo de Medellín y Puebla, ha surgido en el continente la imagen de un "Cristo liberador", proveniente de los evangelios. Este constituye el hecho cristológico mayor y un auténtico signo de los tiempos, pues recuperando la identidad de Jesús de Nazaret el Cristo de la fe ha terminado por recuperar su relevancia histórica (113). La nueva imagen de Cristo es liberadora porque tiene "capacidad de liberar de la diversidad de esclavitudes que afligen a los pobres del continente, de otorgar dirección a esa liberación y de animar a los creyentes a ser sujetos activos de ella" (114). La nueva fe en Cristo liberador se opone a la fe en un Cristo de quien se puede esperar una salvación trascendente pero no histórica (115).

Dentro de la recuperación de la humanidad de Cristo vista anteriormente, su anuncio del reino de Dios a los pobres tiene una importancia decisiva. Esta es la perspectiva en la cual Sobrino comprende la salvación escatológica como liberación histórica. La "práctica con espíritu" de Jesús en favor del reino para los pobres determina la historia que debiera ser "proseguida" (116). Al efecto, Sobrino remesianiza la figura de Jesús. Si el título "Jesucristo" ha perdido todo significado es porque se ha olvidado que "Cristo" alude a la liberación de los pobres. Pero ningún valor tiene llamar a Jesús "Cristo" si no se reconoce en Él un poder -que en su caso no fue el poder físico, militar o político, sino el de la verdad, el amor y el testimonio-, para cambiar la "polis" conforme al advenimiento del reino de Dios. Con la denominación de "liberador" la cristología latinoamericana ha pretendido exactamente recoger lo central del título de Cristo, a saber, que habría de venir uno a traer salvación a los oprimidos, un rey justo que liberaría a las mayorías pobres de sus esclavitudes (117). Habiendo el Nuevo Testamento hablado también de Jesús como de "Evangelio", Sobrino destaca que el modo personal de ser de Jesús, "la misericordia, la honradez, la lealtad, la firmeza de Jesús", es buena noticia y salvación para los seres humanos (118). Pero la recuperación del carácter mesiánico y evangélico de Jesús, que en este caso se invocan para verificar la salvación trascendente como liberación inmanente, suponen como condición ulterior de su comprensión la muerte y la resurrección de Cristo.

Ahora bien, de esta y de aquella Sobrino también destaca su relatividad y valor históricos. Solo porque la cruz de Jesús culmina su vida, su dedicación entera a la proclamación del reino de Dios a favor de los pobres, ella "puede ser comprendida salvíficamente" (119). Solo la perspectiva histórica hace posible entender que la cruz, que siempre es "escándalo" y que ninguna teología puede en realidad "explicar", es expresión del amor de Dios (120). Lo grato a Dios que desencadena su acción liberadora en la resurrección, no es la cruz por sí misma, sino Jesús, su vida y su entrega total (121).

\footnotetext{
(113) Cf. JL 26.

(114) JL 27.

(115) Cf. JL 28.

(116) Cf. JL 76.

(117) Cf. FC 219.

(118) Cf. FC 305.

(119) JL 294.

(120) Cf. JL 294.

(121) Cf. JL 294.
} 
En la resurrección de Jesús se manifiesta por excelencia el carácter liberador de Dios. No porque entonces Dios haya resucitado a un hombre de la muerte. Ciertamente la resurrección de Jesús expresa el triunfo sobre la muerte, pero más precisamente se trata de la acción escatológica por la cual Dios "salva al justo Jesús y hace justicia a la víctima Jesús, y con él se inaugura el final y la plenitud de los tiempos" (122). Al efecto, Sobrino remonta en su argumentación al origen de la fe israelita en la resurrección de los muertos, subrayando que ella surgió como esperanza apocalíptica de las víctimas de la injusticia y que en la resurrección de Jesús se hace realidad como triunfo preciso de la justicia (123).

Este mismo empeño por historizar la salvación cristiana como liberación, es el que llevado a Sobrino a criticar la cristología conciliar y a la patrística que la ha formulado. Pero aunque es de lamentar que la noción de salvación haya olvidado el anuncio de Jesús del reino de Dios a los pobres y se haya formalizado la concepción de Jesucristo, celebra al menos que la patrística comprendió a Cristo en clave soteriológica (124). Las definiciones dogmáticas de Nicea y Calcedonia salvaguardaron la humanidad de Cristo, dejando abierta la puerta para recuperar su historicidad, su conflictividad y sus sufrimientos. La confesión de Calcedonia de la totalidad unificada de Cristo de su humanidad y de su divinidad, constituye la garantía de la salvación (125). La posibilidad de una unión radical del hombre con Dios llegada a ser probable en Jesucristo, un hombre y un Dios crucificado, en principio de la unificación de todos los seres humanos (126).

Tanto desde el punto de vista de la historia de Jesús como desde el de la fe de la Iglesia expresada en los concilios ecuménicos de la antigüedad, surge la imagen de un Dios relacionado esencialmente con la historia humana y como el salvador de ella en cuanto tal (127). Si en Jesús crucificado Dios expresó su afinidad con el sufrimiento de las víctimas de la historia, si existe en Dios la posibilidad de sufrir con los hombres y efectivamente ha sufrido, en la resurrección Dios expresó su alteridad, su ser otro distinto a nosotros, con la capacidad de liberar a las víctimas del sufrimiento, de la injusticia y de la muerte (128). El Dios liberador es el Dios crucificado (129). Esta realidad paradójica de Dios expresa que "no hay liberación del pecado sin cargar con el pecado, que no hay erradicación de la injusticia sin cargar con ella" (130). Aun más, Dios no triunfa simplemente sobre la muerte, consecuencia del pecado y la injusticia, sino sobre los crucificadores. "Si en la cruz Dios parece estar a merced de ellos, en la resurrección se muestra triunfando sobre ellos. Si la cruz simboliza el triunfo de los ídolos sobre Dios, la resurrección simboliza el triunfo de Dios sobre los ídolos. Si en la cruz Jesús es la víctima que los ídolos generan por necesidad, en la resurrección Dios devuelve a la vida a la víctima Jesús" (131).

(122) FC 69.

(123) Cf. FC 69.

(124) Cf. FC 319.

(125) Cf. FC 442-443.

(126) Cf. FC 449-451.

(127) Cf. JL 97.

(128) Cf. FC 134-136.

(129) Cf. FC 136.

(130) JL 313.

(131) FC 131. 
El carácter histórico de la salvación escatológica se deja ver en que por medio de Jesús, el mediador, y su reino, la mediación, Dios ha querido liberar a las víctimas de males muy concretos (132). Los bienes que esta liberación importa son, ante todo, liberación de males históricos. El reino, ayer y hoy, se construye en este mundo en contradicción con el antirreino; supone una conflictividad similar a la de Jesús "contra los opresores históricos (los ricos, los escribas, los fariseos, los gobernantes) y contra el opresor transcendente, el Maligno" (133). El principal mal del cual América Latina necesita ser liberada es la idolatría. Aquí el "ídolo por antonomasia, originante de todos los demás, es la configuración económica de la sociedad, injusta, estructural, duradera, al servicio de la cual están otras muchas realidades: el poder militar, el político, el cultural, el judicial, el intelectual y, también, con frecuencia, el religioso, los cuales participan análogamente de la realidad del ídolo" (134). Esto justifica que la cristología de Sobrino no estructure la salvación en razón de la resurrección, sino del reino de Dios. La salvación como liberación significa evidentemente bienes para los pobres y, por ellos, para todos. Será salvación para los demás en la medida que el reino se traduzca en vida mínima para los pobres (135). Su contenido positivo preciso, sin embargo, se manifiesta históricamente en contradicción dialéctica con la injusticia y la muerte. El contenido sistemático del reino de Dios - como se ha indicado más arriba- es "la vida justa de los pobres abierta siempre a un más" (136).

Si la salvación acontecida en Cristo es una realidad escatológica que tiene un origen, unas características y un contenido históricos, queda ver cómo entiende Sobrino que la liberación se verifica en la historia presente. En este punto llama la atención la originalidad y la audacia de Sobrino. Pues así como él hace depender la salvación de la afinidad y la alteridad de un Dios a la vez crucificado y liberador, en vista de historizar esta salvación en la actualidad declara la presencia de Cristo crucificado en los pobres del mundo y reclama de los cristianos verificar su resurrección mediante un seguimiento resucitado de Jesús.

Si la salvación depende en todo caso de Cristo, son los "pueblos crucificados" los que hacen presente el cuerpo de Cristo en la historia en cuanto crucificado. Los pueblos crucificados incorporan a Cristo a la historia, "completan en su carne lo que falta a la pasión de Cristo" (137). Ellos, en la medida que continúan en el mundo la pasión de Dios, son causa o principio de salvación del mundo (138). Sobrino, consciente de lo escandalosa de esta tesis, la asimila al escándalo que debiera siempre provocar la fe en la salvación mediante el siervo Jesús y el Dios crucificado (139).

(132) "La salvación que trae el reino -aunque no se agote en ello- será, entonces, la salvación histórica de los males históricos. En qué consistan los bienes del reino viene determinado, ante todo, por la situación concreta de los seres humanos oprimidos y no por una decisión a priori de lo que sea la salvación" (JL 167).

(133) JL 167

(134) JL 243.

(135) Cf. JL $117 \mathrm{~s}$

(136) JL 173.

(137) JL 322.

(138) Cf. JL 328.

(139) Cf. JL 328; 330, 477. 
Al menos exige que se reconozca que estos pueblos ofrecen al mundo la posibilidad de conversión, valores, esperanza, amor, perdón, solidaridad y fe (140).

En el presente histórico la liberación escatológica se verifica mediante un seguimiento de Cristo que arraiga entre los pobres del mundo y su praxis consiste fundamentalmente en "resucitar a los crucificados" o "bajar de la cruz al pueblo crucificado" (141). Así, no de otro modo, es posible acceder a la realidad de la resurrección de Cristo y dar testimonio de ella. La esperanza que la resurrección genera "versa en directo sobre la justicia, no simplemente sobre la supervivencia; sus sujetos primarios son las víctimas, no simplemente los seres humanos; el escándalo que debe superar es la muerte infligida injustamente, no simplemente la muerte natural como destino. La esperanza que hay que rehacer hoy no es una esperanza cualquiera, sino esperanza en el poder de Dios contra la injusticia que produce víctimas" (142). Por esta vía la fe en la resurrección es liberadora. Ella añade algo sustancial al seguimiento de Cristo: la definitividad y la necesidad de integrar la cruz en la experiencia de un Dios que se deja afectar por el sufrimiento humano (143).

\section{ALGUNAS OBSERVACIONES CRÍTICAS A LA CRISTOLOGÍA DE JON SOBRINO}

Las críticas que pueden hacerse a la cristología de Jon Sobrino son de distinta índole, pero también de diverso calibre. Habiéndose asumido en este artículo la perspectiva de la historicidad de la salvación cristiana, bajo este mismo respecto avanzamos un par de objeciones a la articulación liberadora de la cristología de Sobrino.

\section{a) Simplificación metodológica}

En Sobrino el "desde abajo" antioqueno experimenta una ampliación metodológica: no solo conocemos a Cristo a partir de Jesús, sino que a Jesucristo lo conocemos a partir de los pobres. Este conocimiento, a su vez, estimula en circularidad hermenéutica la liberación de los pobres. Pero ¿a qué pobres se refiere esta posibilidad? Es más, ¿de qué liberación se trata?

Si el objeto de la cristología es Jesucristo, a este objeto Sobrino accede no solo por los textos que hablan de Él sino también por la presencia actual del mismo Cristo en el mundo, verificable en el seguimiento suyo solidario con los pobres y las víctimas. En este sentido el objeto de la cristología no es solo el Jesús histórico (punto de partida metodológico), sino también el Cristo de la fe que surge de la experiencia subjetiva que la Iglesia hace de Él (punto de partida real). Si tal es el objeto, el sujeto para la cristología latinoamericana es una vez más aquel que, bajo

(140) Cf. 331-333.

(141) Cf. FC 76-79.

(142) FC 70.

(143) Cf FC 155. 
el influjo del Espíritu y de la gracia, sigue a Cristo en un mundo de pobres y de víctimas. La circularidad hermenéutica caracterizada por esta imbricación de objeto y sujeto de la cristología se prolonga en el tiempo, revelando siempre de un modo nuevo a un Dios que puede cambiar la historia en favor de los marginados. Este planteamiento nos parece un aporte enorme a la relevancia de la teología y, especialmente, a la clásica cuestión de la relación entre el Jesús histórico y el Cristo de la fe.

La opción de una perspectiva en cristología tiene siempre un precio, se la declare o no y, como bien enseña Sobrino, no es posible no optar. En su caso, sin embargo, la perspectiva es reoptada en simplificaciones de la realidad que, si en lo inmediato movilizan la verificación de la salvación histórica de los pobres, a largo plazo pudieran frustrarla gravemente. Una simplificación es la que establece Sobrino entre oprimidos y opresores; otra, la que hace diferencia entre los pobres que poseen una imagen alienante de Cristo y aquellos que creen en un Cristo liberador.

La distinción tajante entre oprimidos y opresores pone de relieve la verdad de un conflicto que suele darse también fuera de los límites de la Iglesia. Sobrino no teme entrar en este conflicto. Lo hace tomando partido por los oprimidos. En su caso se invoca no solo la parcialidad de Dios, sino sobre todo la posibilidad de salvación para el resto de la humanidad. Ellos, al incorporar a Cristo en la historia, mediatizan sacramentalmente su salvación. Ahora bien, esta identificación de las víctimas históricas con el "cuerpo de Cristo" es problemática en dos sentidos. En primer lugar, la categoría de "cuerpo de Cristo" en la teología se ha aplicado normalmente a la Iglesia. Sobrino aplica el término a la Iglesia (144), pero sin solución de continuidad, sin distinción ni fundamentación suficiente, lo usa también para referirse a los pueblos del Tercer Mundo (145). De ello resulta que la función sacramental de la Iglesia, en cuanto "cuerpo de Cristo", se desdibuja, haciéndose hasta cierto punto superflua. Los "pueblos crucificados" parecen ocupar su lugar. Queda así pendiente en esta cristología que, de ser posible fundamentar la aplicación de esta categoría a las víctimas del Tercer Mundo, se establezca la distinción tanto como la vinculación entre los pueblos crucificados y la Iglesia. En segundo lugar, habiendo desarrollado Sobrino la semejanza entre Cristo y estos pueblos mediante las figuras del siervo sufriente y el martirio, no ha hecho lo mismo con la diferencia entre aquellos. En suma, la identificación del mundo de los pobres con el "cuerpo de Cristo" simplifica la realidad concentrando en ellos la salvación y en los opresores todo lo contrario; lo cual puede ser válido bajo algún, pero no bajo todos los respectos.

Advertimos, además, una segunda simplificación. Topamos aquí con una falla o una inconsecuencia metodológica, pues si el mérito de Sobrino estriba en derivar el conocimiento cristológico del seguimiento de Cristo, este autor no es suficientemente concreto o "real" como él mismo reclama que serlo sea, cuando reduce la realidad de los latinoamericanos a la de las víctimas. Aunque sea cierto que los latinoamericanos en su inmensa mayoría son víctimas, no son solo víctimas. En tanto creyentes, no es posible despreciar como ideológicas las muy diversas mediaciones culturales y religiosas de la fe de las víctimas. Los latinoamerica-

(144) Cf. JL 45, 49, 51; FC 241.

(145) Cf. JL 321-322. 
nos, además de pobres y cristianos, tienen una cultura y en esa cultura han acogido y reproducido su fe cristiana, aun cuando haya en todo ello mucha ambigüedad. La cristología de Sobrino nos parece ilustrada: quiere ser "popular", pero rompe con la religiosidad popular; arraiga en general en los pobres del Tercer Mundo, pero, en particular, en aquellas comunidades que confiesan su fe en el Cristo liberador a las que el autor ofrece su servicio de teólogo (146).

Esta segunda simplificación opera calladamente, pero no es claro que opere sin menoscabar la cultura popular. El método de la cristología de Sobrino acierta en lo fundamental, pero extravía el rumbo cuando no respeta la realidad misma de la fe en Cristo en el continente. No vemos cómo, sin reconocerse valor a la religiosidad popular, la ruptura cristológica que se pretende pueda no desembocar en una lamentable iconoclasia eclesial. El método cristológico de Sobrino aún debiera formular las vías que articulen la continuidad de la fe popular en Cristo salvador con la discontinuidad proveniente de la ilustración sobre la imagen de Jesucristo liberador proveniente del Nuevo Testamento y del seguimiento de Cristo (147). Solo así, accediendo a la "realidad" más profunda de Cristo entre los pobres y las víctimas, que tienen múltiples modos de creer y de luchar por la vida, la cristología podrá superar las alienaciones que se siguen de antiguas y nuevas abstracciones.

\section{b) Desequilibrio sistemático}

Desembocamos en la crítica más seria que puede hacerse a la cristología de Sobrino. Las simplificaciones concernientes a los pobres recién descritas tienen lugar al interior de una simplificación de la realidad en su conjunto, todo lo cual conspira en contra de la deseada liberación. Desde el momento que la teología latinoamericana aspira a verificar la salvación escatológica como liberación histórica, esta cristología se ve desafiada a establecer las condiciones de posibilidad teológicas, pero también racionales de su intento. Pues bien, en este plano el sistema cristológico levantado por Sobrino resulta desequilibrado y su oferta de liberación inverosímil.

En contra de una representación ingenua e ideológica de la reconciliación escatológica, que varias veces se ha articulado en América Latina como una búsqueda de paz pero sin lucha y conflicto por la justicia (148), Sobrino reclama una reconciliación que supere la "estructura teologal-idolátrica de la realidad" (149). En este esquema empero la separación entre opresores y oprimidos es tan nítida como problemática. La resolución de esta representación global de la realidad depende de la "parcialidad" de Dios que actúa a favor de las víctimas y en contra de los victimarios. Pues bien, no se puede dudar que la cristología de Sobrino aspira a la universalidad y a la reconciliación de las partes en conflicto (150). El autor es consciente de

(146) Cf. JL 20 y FC 19-20.

(147) Esta importante sugerencia es la que hace Juan Carlos Scannone en Evangelización, cultura y teología, Ed. Guadalupe, Buenos Aires, 1990, pp. 237-243.

(148) Cf. JL 31.

(149) Cf. JL 213.

(150) "La totalidad, no lo fragmentario; la unidad, no la disgregación; la reconciliación, no el antagonismo es lo que salva" (FC 445). 
la polaridad teológica entre lo parcial y lo universal (151). Hemos visto que, en virtud de Cristo, la realidad última es una, que toda forma de dualismo debe ser rechazada. Sin embargo, precisamente allí donde llega a esta conclusión no desarrolla sistemáticamente la resolución de la dialéctica/conflicto de la realidad, sino que ella queda implícita y entregada al misterio de Dios que habita en la fórmula de Calcedonia, salvaguardado con adverbios negativos (152). Es decir, Sobrino no explicita las vías de resolución del conflicto histórico-escatológico inherente a la entera concepción de la liberación que promueve.

No se trata simplemente de criticar la también llamada en América Latina "lucha de los dioses", que la "estructura teologal-idolátrica de la realidad" especifica. El conflicto es una realidad de la vida y de la historia humana. Recuperarlo conceptualmente es un imperativo de pertinencia para la teología latinoamericana, pero así como su negación importa riesgos, también los importa su mera proclamación. Es cierto que a $\mathrm{Fe}$ en Jesucristo no puede pedírsele abordar problemas que una cristología en regla exige. Esta obra no pretende ser más que un ensayo. Pero la tesis en cuestión es de tal envergadura que el lector atento espera verla replanteada en un capítulo conclusivo o siquiera en el capítulo dedicado a "Dios en la historia: pathos de totalidad" (FC, capítulo18), y no lo ve. La perspectiva dialéctica/conflictiva, sin embargo, termina por imponerse a lo largo de ambos libros, impidiendo que una perspectiva unitiva/reconciliatoria equilibre la cristología en su conjunto.

Por último, así como a la propuesta de liberación de Sobrino le ha faltado elucidar las vías de la superación del conflicto histórico, tampoco ha incursionado en las mediaciones racionales de una sociedad más justa. La promoción de la salvación como una realidad meramente trascendente, después de la Teología de la liberación, no tiene futuro en América Latina. Pero la legítima exigencia de inmanentización de la salvación escatológica pone a esta teología problemas teóricos difíciles de enfrentar. Sobrino considera de importancia secundaria, pero no prescindible, el recurso a las ciencias sociales, pues más importante le parece la ruptura epistemológica de la cristología, mirar a Cristo en la perspectiva de los pobres (153). Con mayor razón rechazaría vincular la cristología a propuestas precisas de cambios sociales, económicos y políticos. Pero se echa de menos en su cristología la sugerencia de un empalme entre el Jesús de Nazaret que merece un seguimiento de fe y el Cristo que subyace en la racionalidad del cosmos, el Cristo que urge en creyentes y no creyentes, en oprimidos y opresores, esfuerzos de inteligencia por inventar un mundo mejor. No podemos olvidar que el Dios salvador es el Dios creador, que es uno y el mismo Dios el que nos libera y nos mueve a inventar la liberación. En la cristología de Sobrino no se da un predominio del Jesús histórico sobre el Cristo de la fe, sino una concepción del Cristo de la fe restringida a un modo de entender la figura histórica de Jesús y de su liberación que, sin embargo, no interactúa suficientemente con el Logos inmanente al resto de la humanidad y que también de ella pide un compromiso de transformación de la historia humana. Paradójicamente, cabe aquí el peligro de recaer en la espiritualización de la salvación que se combate. Si de liberación histórica se trata, preciso es recurrir al Dios que por Cristo salva a través de la fe y de la razón.

(151) Cf. FC 320.

(152) Cf. FC 424.

(153) Cf. JL 52. 


\title{
RESUMEN
}

Este artículo se limita a dar cuenta de los trazos principales de la cristología de Jon Sobrino, en lo que respecta a su dimensión soteriológica. La liberación de los pobres y de las víctimas constituye el motivo que impulsa la reflexión de este destacado cristólogo latinoamericano y caracteriza su articulación sistemática. En esta perspectiva se analiza la ruptura metodológica que su cristología pretende representar; la doble referencia de Cristo al reino de Dios y al Dios del reino; la recuperación de la humanidad de Jesús; y la verificación de la salvación escatológica como liberación intrahistórica. En las páginas finales de este artículo se ofrecen algunas consideraciones críticas.

\begin{abstract}
This article gives account of the main points of Jon Sobrino's Christology concerning its soteriologic dimension. The liberation of the poor and the victims lies at the bottom of the reflection of this renowned Latin American Christologist, and characterizes his systematic articulation. This article analyses the methodological break-up which his Christology attempts to represent. These are Christ's double reference to the kingdom of God and God of the kingdom; the recuperation of Jesus' humanity; and the verification of the eschatological salvation as an intra-historical liberation. On the lasts pages, the article offers a few critical considerations.
\end{abstract}

